\title{
Integrating Gandhian Conflict Resolution Techniques in Legal Studies: An Indispensable Path for Legal Professionals
}

\author{
S. Saba \\ Aligarh Muslim University, Aligarh, Uttar Pradesh-202001, India
}

Corresponding author: shadowcat03saba@gmail.com

Received: 16 Jan., 2019

Revised: 17 Apr., 2019

Accepted: 19 May, 2019

\begin{abstract}
The Gandhian approach to conflict resolution is an important strategy to encourage mediation and negotiation in the legal system. Right from the first legal case which Mahatma Gandhi handled in South Africa to his time-tested strategies of resolving conflicts through nonviolent means - all offers legal practitioners a bouquet of options to strengthen arbitrations in the country when the number of court cases are rising every year. This chapter will try to capture the Gandhian methods which have assumed significance in order to try and reduce the burden on the judiciary.
\end{abstract}

Keywords: Gandhian conflict resolution, arbitration, alternate disputes resolution

Conflict resolution to Gandhi meant not just the elimination of maladjustment. It rather meant for him progress towards more and more meaningful adjustments. This can be achieved only when violent relationships are transformed into non-violent relationships where the energies of the opponents are utilized to achieve a higher integration. Also it needs to be underscored that Gandhian non-violent communication focuses on identifying the needs of individuals and groups instead of the assigning blame for circumstances; it has the potential to heal the wounds most of us feel deep inside us. These perspectives hold great importance in the legal system as the courts in our country face immense pressure due to mounting number of cases.

In his autobiography, Mahatma Gandhi gives poignant details of his efforts to settle a legal case through arbitration while in South Africa. When he settled his first legal case in South Africa, he did so by arbitration, i.e. out of court. He even persuaded his client, Dada Abdullah to take payments from the losing party, Abdullah's cousin, in instalments so as not to ruin him. In doing so, Gandhi learned first-hand the value of mediation, conflict resolution, and compromise. These early experiences would deeply influence Gandhi's conciliatory conflict resolution approach.

It would be pertinent to quote Gandhi from "The Collected Works of Mahatma Gandhi" where his experience after such an effort in arbitration has been described "...both were happy with the result, and both rose in public estimation. My joy was boundless. I had learnt the practice of law. I had learnt to find out the better side of human nature and to enter men's hearts. I realized that the true function of a lawyer was to unite parties as under. The lesson was so indelibly burnt into me that a large part of my time during the twenty years of my practice as a lawyer was occupied in bringing out private compromise of hundreds of cases. I lost nothing thereby-not even money; certainly not my soul." 
We have to understand that legal system is the primary institutional solution to conflict resolution among individuals and groups. It generally precludes the Gandhian dialect from coming into play because it is concerned with "sanctions" and not with reconciliation and compromise, least of all conversion. One of the parties in conflict risks total loss and usually both incur costs. Unlike Gandhi's satyagraha which is based on the Indian tradition, stresses dialogue, mediation and compromise and de-emphasizes overt clashes, victories and defeats the western approach stresses "legal" resolution of conflicts involving articulation and confrontation of alternatives/opposites and victory of one over other. The parties generally interact through professional lawyers. Gandhi, himself a lawyer saw lawyers as mediators rather than mere conductors of legal proceedings. Gandhi wanted to evolve a revolutionary approach to political action and social change. His originality lay in the formulation of a new technique of non-violent non-cooperation or Satyagraha for social action. He believed that Satyagraha is an infallible means for resolving all social, political, and economic evils. As a technique of social action, satyagraha may be applied to resolve the following type of social conflicts:

(i) conflict between one individual and another individual

(ii) conflict between an individual and a group

(iii) conflict between one group and another group or between two classes

(iv) conflict between a section of the community and the state

(v) conflict between one nation and another nation

Gandhi's writings often refer to arbitrations and even judicial adjudication as ways of resolving conflicts. Gandhi had died decades before the advent of the Alternate Disputes Resolution (ADR movement) or before conflict resolution movement or conflict resolution literature had brought some sense of order to the terminology used in the field; it is therefore not surprising that he used the term 'mediation' interchangeably with 'arbitration.'
The modern ADR movement has aimed at avoiding legal adjudication and giving disputants a measure of control over the outcome of disputes in something of a Gandhian spirit through the good offices of a mediator. It is the mediator's job to assist the parties to come to their own resolution of their dispute. There is no power to compel settlement; the disputants must rely on their own mutual agreement with assistance from the mediator and, because it is in their interest, they themselves make settlements work. While the outcome sought is an accommodation between the parties, it could lead to the conversion aimed at by satyagraha and so come close to Gandhian ideal. In other words, this level of third party involvement is not totally outside the parameters of the ideal Gandhian conflicting process, as adjudication or even arbitration would be. After all, Gandhi himself took pride in being a third party assistant in so many disputes. In short, the Gandhian conflict process is generally seen as a bilateral one, Gandhi himself may have perceived a role for mediators as advocated by the champions of transformative conflict as aiding in spiritually and morally enriching process by not merely going beyond issues of power and rights.

Gandhi gave the theory and practice of nonviolence, practised it in his daily life and used it to resolve conflicts. No one has done more to develop and popularize the tool of non-violent action than Gandhi. For Gandhi, non-violence meant not merely non-injury, but active love and the positive will to sacrifice one for the sake of others, the use of non-violence for the redressal of grievances and the correction of mistakes would not normally provoke any unfavourable or undesirable adverse reactions in the opponent. Under the moral pressure of non-violence one was more likely to introspect and change his position than if he were threatened by the weapon of violence. Resolution of conflict without allowing it to go through court proceedings has been a cause dear to the Gandhian agenda. As a lawyer, Gandhi always tried to settle conflicts outside the court system even while collecting his regular fees. The modern ADR movement has established a method for avoiding adjudication by giving the disputants some degree of control over 
the outcome of the dispute in a Gandhian spirit through the good offices of a third party. Gandhian method of dispute resolution influenced the ADR movement in India thus Gandhian mode of dipute resolution is transformative and suitable to the social conditions of the people of India. We can rightfully argue that Gandhi is the forerunner of ADR in India and his model of dispute resolution represents an appropriate dispute resolution model.

Individuals, corporations, and government agencies use these methods widely, but do not realize that such actions might be characterized at the common law as an alternative to litigation which can be called as "mediation" in Gandhi's words.

We can conclude that the Modern conflict resolution theory is very much similar to the concept of ADR Gnadhiji concocted infact many of Gandhi's own statements readily reflect these principles: 'A Satyagrahi must never forget the distinction between evil and the evil-doer.'

Even though Gandhi provides a workable mechanism of conflict resolution, it has not received much attention to a larger extent. Many works have been brought out in recent years that laid emphasis on the relation between Gandhian ethics and conflict resolution.

Due to extremely slow judicial process, there has been a big thrust on ADR mechanisms in India. The Law Commission in its working paper on 'Alternative forum for Resolution of Disputes at Grass root Level' has observed that the present system of administration of justice is not suited to the needs of our people and the real remedy lies in reforming the existing judicial system by undertaking some interim steps immediately. ADR has been a vital, and vociferous, vocal and vibrant part of our historical past. Conciliation cells operating regularly in certain rural areas of Tamil Nadu are settling a large number of pre-litigation disputes almost on the pattern of the Lok Adalats. Some traditional community dispute resolution systems like tribal council of Malana village in Himachal Pradesh, do not give emphasis on procedural aspect of law.

PRINT ISSN: 2321-9807

\section{Current position of ADR in India}

Alternative dispute resolution is not new to India. The concept is analogous to the panchayat or similar bodies consisting of influential and elderly men from the community who were bestowed with power to manage of religious and social functions and who were called upon to decide the dispute between parties in the particular village, be it civil or criminal or revenue.

Lok Adalat is an ADR forum which has the potential of increasing access to justice. They are informal, flexible, participatory forums which have as their purpose the encouragement of settlements, compromises and the avoidance of litigation. Lok Adalats serve as mediatory and conciliatory forums which are voluntarily utilised by parties to a dispute as a means of understanding their rights and obligations under the 'rule of law' and of facilitating the settlement or compromise of their disputes. Lok Adalats have no legal authority to impose their decisions.

People's Court of Parikh is considered as a precursor to Lok Adalats movement in India. 'It was through his role as a mediator in village disputes that the leader of Lok Adalats, Parikh attained legitimacy, and a degree of charisma. In turn, he used Lok Adalats to translate his vision of socio-economic reforms by making it a vehicle of reform-oriented adult education. ${ }^{1}$

India partially embraced Lok Adalats - village level people's courts - in the 1980s, where trained mediators sought to resolve common problems that in an earlier period may have gone to the panchayat. Panchayati justice is an ancient institution in India with its roots deep in the ethos of the country. An important innovation since independence is that of the Panchayati Raj system which incorporated the activities of community development and the system of Nyaya Panchayats (NP) for local dispute resolution. NPs were resolving disputes in accordance with the local customs. With the advent of British colonialism NPs role was diminished. At the same time, just as article 40 of the constitution

${ }^{1}$ Dr. Laju P. Thomas, Dispute resolution in rural India: An overview, http:// jlsr.thelawbrigade.com/wp-content/uploads/2016/11/Laju.pdf 
directs the States to organise village panchayats, another directive principle (article 50) directs it to take steps to separate the judiciary from the executive. Some regions like, Madras, Mysore and Kerala had a system of village courts at the time of the adoption of the constitution. But few States implemented article 50 upon the adoption of the constitution by creating separate NPs. Several committees and commissions have studied the panchayati justice system and they recommended for revitalising this traditional institution.

Arbitration in India was enshrined in three different enactments, namely, The Arbitration Act, $1940^{2}$, the Arbitration (Protocol and Convention) Act, 1937 and the Foreign Awards (Recognition and Enforcement) Act, 1961. The Arbitration Act laid down the framework within which domestic arbitration was conducted in India, and the other two Acts dealt with foreign awards. The Arbitration and Conciliation Act, 1996 has repealed the three past acts, consolidated and amended the law relating to domestic arbitration, international commercial arbitration and enforcement of foreign

${ }^{2}$ Arbitration Act, 1940 http://www.advocatekhoj.com/library/bareacts/ arbitration/index.php?Title=Arbitration\%20Act, $\% 201940$ arbitral awards and also defines the law relating to conciliation, providing for matters connected therewith and incidental thereto on the basis of the Model Law on International Commercial Arbitration adopted by the United Nations Commission on International Trade Law (UNCITRAL) ${ }^{3}$ in 1985. This is the current position in India.

\section{CONCLUSION}

ADR system is there in the Indian legal curriculum; future legal professionals do read about the nuances of ADR. There are many ADR centres in various law schools to teach the applied ADR methodology but it is seen that the legal regime is burdened with lakh of cases cause matters of dispute mostly reach the court of law. Outside court settlement is hardly opted for the day to day cases although mechanism is present. Whenever matter reaches court of law; it is either win or loss situation, leaving aside the time and energy it consumes. "Gandhian conflict resolution and nonviolent communication-an indispensable path for legal professionals."

${ }^{3}$ India: Alternate Dispute Resolution (ADR) In India (11 December 2017), http://www.mondaq.com/india/x/654324/court+procedure/ Alternate+Dispute+Resolution+ADR+In+India 